1995 году бронзовая скульптурная композиция «Манас» была установлена в здании ООН в США.

Большую историческую и художественную ценность представляет созданная Садыковым портретная галерея исторических личностей Юсуфа Баласагунского, Махмуда Кашгарского и других, образы которых были реконструированы по историческим материалам. В портретную галерею художника входит огромное количество ликов его современников. Почти все движители» киргизского общества и его культуры - люди значительные, цельные, творчески деятельные натуры, внесшие весомый вклад в сокровищницу национальной культуры. Среди них - писатель Чингиз Айтматов, президент Аскар Акаев, философ Азис Салиев, хирург А. Круглов, поэт Омора Султанова, актрисы Даркуль Куюковой, кинорежиссера Толомуша Океева, министра культуры К. Кондучаловой, геолога Ш. Текенова, радиобиолога $\mathrm{C}$, Даниярова, академиков $\mathrm{K}$. Отурбаева, А. Мурзалиева, А. Какеева и многих, многих других.

Портретные работы Садыкова настолько значительны, что в республике был создан специальный музей скульптуры им. Тургунбая Садыкова, в котором теперь представлен скульптурный эпос киргизского народа, созданный им. В свое время, изучая античную историю, А.И. Герцен заметил, что все особенности культуры Древнего Рима можно постигать по гениальному римскому скульптурному портрету. Сегодня историю киргизской культуры и ее деятелей, действительно, тоже можно познавать, обращаясь к мощному скульптурному наследию Садыкова.
В заключении отмечу, что страстная детская мечта быть художником, обязательно скульптором, вера в своё предназначение и неустанный творческий труд сделали эту мечту Садыкова яркой явью современной истории киргизского искусства.

\section{Список литературы}

1.Айтматов Чингиз. Статьи, выступления, диалоги, интервью. - М.: Изд-во Агентства печати Новости, 1988, С.20

2.Мосолова Л.М., Бондарев А.В., Уланова. А.А. Культурологический анализ институтов традиционной культуры киргизских номадов (на примере детского художественного творчества)//

Общество. Среда. Развитие. 2020, №1. С

3.Садыков Т. Крылья. Лит. запись Ю.

Бычкова. М., Молодая гвардия».1976. С.7-8

4.Там же. С. 9

5.Там же. С. 10

6.Там же. С. 11

7.Там же.

8.Айтматов Ч. В соавторстве с землею и водою (очерки, статьи, беседы и интервью). Фрунзе: Кыргызстан, 1978. С.103.

9.Прыткова Л.А. Тургунбай Садыков, скульптура. Бишкек, 2005. С. 9

10.Там же. С. 19.

11.Там.же.С.46

12.Мосолова Л.М., Прыткова Л.А. История искусства Кыргызстана: в 2т. Т.2: ХХ-нач. XX1века: монография, - СПб., Бишкек: Изд-во РГПУ им. А.И. Герцена, 2019.С.241-242.

УДК 782

ГРНТИ 18.41 .51

ПРАКТИЧЕСКАЯ РАБОТА ПО ПОСТАНОВКЕ ГОЛОСА, ЧАСТЬ ІІІ. РАБОТА НАД ГОЛОСОМ

Покровский Андрей Викторович член-корреспондент Петровской Академии наук и искусств. Россия, г.Санкт-Петербург

\title{
PRACTICAL WORK ON VOICE TRAINING, PART III. WORKING ON THE VOICE
}

\author{
Pokrovskiy A. V. \\ corresponding member \\ of the Peter Academy of Sciences and arts. \\ Russia, St. Petersburg \\ DOI: 10.31618/ESU.2413-9335.2020.6.76.934
}

\section{ABSTRACT}

The article examines the General provisions of vocal pedagogy: the relevance of the issue, principles, goals, objectives and methods of teaching singing; the criteria, methods of selection and basic skills necessary for those wishing to learn vocal art.

\section{АННОТАЦИЯ}

В статье исследуются общие положения вокальной педагогики: актуальность вопроса, принципы, цели, задачи и методы обучения пению; рассматриваются критерии, способы отбора и основные навыки, необходимые для желающих обучаться вокальному искусству.

Key words: vocal, singing, academic singing, vocal pedagogy, voice production, methods of teaching singing. 
Ключевые слова: вокал, пение, академическое пение, вокальная педагогика, постановка голоса, методы обучения пению.

При планировании уроков вокала необходимо помнить, что вся работа должна быть направлена на поддержание интереса к вокальному творчеству, развитие музыкальных способностей и овладение вокально-техническими навыками. Уроки пения должны помочь обучающимся стать свободными и артистичными, а все этапы работы должны способствовать лучшему исполнению учебного, концертного и конкурсного репертуара.

\section{Тип голоса}

В самом начале работы с вокалистом перед каждым педагогом встает необычайно важная задача - верно определить тип голоса учащегося. Именно от этого этапа во многом зависит благополучное формирование и развитие голосового аппарата начинающего певца. Перед тем, как приступить к занятиям, необходимо пройти осмотр у врача-фониатра. Это поможет определить верный голосовой режим для занятий, поскольку выявит состояние связок, слизистых оболочек и специфику голосового аппарата.

Педагогу необходимо быть особенно внимательным на этом этапе, поскольку у начинающих профессиональные занятия тип голоса часто бывает выражен не однозначно. Поэтому, производя диагностику, важно опираться не на отдельные, а на всю совокупность признаков тембра голоса. В некоторых же случаях определить тип голоса становится возможным только в процессе занятий, когда певец осваивает близкую его голосу манеру звукообразования.

\section{Дыхание}

В начале обучения пению первостепенной задачей является постановка дыхания. Это недолгий процесс, в среднем занимающий месяцдва регулярных занятий. При этом важно стразу попасть к опытному специалисту, чтобы потом не переучиваться. Данному этапу необходимо уделить особое внимание и периодически возвращаться к нему, повторяя дыхательные упражнения в качестве разогревающей гимнастики перед распеванием.

Основные задачи работы по постановке певческого дыхания:

•Укрепление мышц лица, грудной клетки и брюшного пресса.

•Профилактика болезней верхних дыхательных путей.

-Повышение когнитивных способностей.

-Нормализация звукообразования.

-Использование мышц брюшного пресса и диафрагмы для снятия нагрузки и зажимов с мышц горла

Контролировать правильность дыхания можно при помощи собственной ладони, если положить ее на область диафрагмы. Это поможет контролировать правильность работы мышц живота и грудной клетки.

Звуковедение
Звуковедение собственно и есть пение. Это понятие учащийся должен усвоить в первую очередь. Все звуки должны быть сформированы в единой певческой позиции и связаны между собой в соответствии с закономерностями мелодики и музыкальной фразировки, с хорошей опорой на дыхание.

Для освоения ровного звуковедения можно использовать старый профессиональный прием: «выбросить» из текста все согласные звуки, пропевая и связывая между собой лишь гласные. После того, как все гласные будут звучать в одной позиции, можно приступить к работе по формированию в том же позиционном месте всех согласных.

Легато

Прием легато является основной формой певческого звуковедения, характеризующийся плавным, льющимся, свободным и однородным характером звука. Отрабатывая этот прием, необходимо следить за тем, чтобы максимально долго пропевались именно гласные звуки, а согласные произносились коротко. Переходы от одного звука к другому так же должны быть плавными и ровными. Вырабатывается такое пение постепенно вместе с освоением правильного звукообразования и ровного, плавного выдоха.

Упражнения для освоения такого пения необходимо усложнять и расширять очень медленно, начиная с самых простых. Этот постепенный переход к сложному материалу позволит петь связно все более и более длинные и трудные музыкальные фразы, позволяя следить за правильным формированием гласных. Освоив таким образом основные навыки, можно переходить к пению вокализов, а затем к несложным произведениям с текстом.

Работая над текстом, вначале хорошо предложить ученику исполнить произведение, подобно вокализу, на одном удобном гласном звуке. После того, как мелодия будет освоена, можно переходить к пению произведения с текстом.

\section{Стаккато}

Прием стаккато предполагает отрывистое, короткое звучание с небольшими толчкамиакцентами на слогах. То есть, каждый звук не связывается с другим, а наоборот, отделяется от него.

При выработке этого приема, необходимо обратить внимание на то, чтобы все звуки были короткими, и после каждого отдельного звука присутствовала длительная пауза. Отрабатывая данный тип звуковедения, важно брать дыхание не произвольно на любой паузе, а только между фразами. Голос при этом должен быть легким, светлым и упругим. При выполнении этого штриха необходимо обратить внимание на правильный перенос слогов. Если слог заканчивается на согласный звук, то этот звук переносится к 
следующему слогу, за исключением случаев, когда согласным заканчивается слово.

Нон легато

Между приемами легато и стаккато существует промежуточный вариант звуковедения - нон легато. Он характеризуется не плавным, связным пропеванием звуков, а разделением их очень короткой цезурой, что способствует некоторому подчеркиванию отдельных слогов.

Данный прием объединяет в себе манеру исполнения и легато, и стаккато. Работая над ним, важно следить за тем, чтобы между звуками не было откровенных пауз и резких акцентов, но, в то же время каждый отдельный звук должен быть ясным, отчетливым и выразительным.

\section{Подвижность}

Работа над этим приемом способствует тому, что гортань становится более эластичной и упругой, что важно для исполнения сложных технических пассажей. Начинать работу по развитию подвижности голоса можно только после освобождения гортани от типичных зажимов. На первых этапах важно использовать простые, небыстрые по темпу упражнения, чтобы не переутомить гортань. При этом важно следить за ритмичностью, точностью интонации, а также отсутствием подъездов и скольжений звука. В качестве упражнений можно использовать гаммы в диапазоне октавы. Для улучшения четкости можно исполнят достигает активной фазы: голосовые связки увеличиваются в размере, грудная клетка расширяется и голос постепенно начинает приобретать свое взрослое звучание. В этот период диапазон сам расширяется в различные стороны. Предметно заниматься расширением диапазона можно начинать постепенно только после окончания мутационного периода.

Диапазон голоса состоит из следующих зон:

- примарная зона - середина диапазона, высота, на которой исполнителю удобно говорить и петь. С нее и нужно начинать различные упражнения по расширению диапазона.

- рабочий диапазон - участок голоса, на котором удобно петь вокальные произведения. Он значительно шире примарной зоны. Для расширения этого участка и предназначены все упражнения по расширению диапазона.

- общий нерабочий диапазон - полный охват звучания голоса, включающий рабочие и нерабочие ноты. Он выявляется во время пения распевок и упражнений. Чем шире будет этот диапазон, тем более сложные по тесситуре произведения станут доступны исполнителю.

Расширением диапазона, используя специальные упражнения, можно заниматься исключительно под руководством опытного педагога. В противном случае это может привести к горловому пению, зажимам и профессиональным заболеваниям.

\section{Интонация}

Недостаточно чистая интонация у певца бывает либо по причине отсутствия координации слуха и голоса, либо при плохо развитом слухе. И то и другое улучшается при непрерывном контроле со стороны, сознательном самоконтроле и упорном труде исполнителя. Любой сложный для исполнения интервал или отрывок произведения нужно отрабатывать, используя прием легато. Можно так же транспонировать его вниз или вверх (на $1 \backslash 2$ тона, на 1 тон), пропевая этот «кусочек» как вокальное упражнение.

\section{Дикция}

Вокальная речь должна быть разборчива, естественна и выразительна. Произнесение текста во время пения не должно мешать звуковедению и искажать гласные. Для того, чтобы не нарушалась ровность вокальной линии при активном произнесении текста, все согласные необходимо произносить коротко, а гласные, наоборот, немного растягивать. Для ровного звуковедения при пении интервалов гласные должны быть произнесены в одной позиции с согласными и на одном звуковысотном уровне с ними.

Довольно часто встречается нечеткое произнесение согласных в конце фраз. Это происходит по причине ослабления артикуляции согласного вместе с окончанием звучания. Результатом является вялое или почти не уловимое на слух окончание слов. Такая проблема исправляется использованием специальных артикуляционных упражнений и скороговорок для тренировки работы губ. Явные же дефекты в произнесении отдельных согласных - картавость, гнусавость, шепелявость и т.д. - необходимо исправлять при помощи логопеда.

\section{Список использованной литературы:} 2000

1.Багадуров В. Вокальное воспитание. - СПб.

2.Варламов А. Школа пения. - СПб. 2008

3.Выготский Л. Психология искусства. - М. 2018

4.Гарсиа М. Полная школа пения. - М. 1957

5.Далецкий О. Школа пения. - М. 2007

6.Дейша-Сионицкая М. Пение в ощущениях. СПб. 2014

7.Дмитриев Л. В классе профессора М.Э. Донец-Тессейр. - М. 1974

8.Дмитриев Л. Основы вокальной методики. М. 2000

9.Емельянов В. Развитие голоса. - СПб. 2003

10.Кабалевский Д. Воспитание ума и сердца. M. 1981

11.Лемешев С. Путь к искусству. - М. 1982

12.Матонис В. Музыкально-эстетическое воспитание личности. - Л. 1988

13.Морозов В. Искусство резонансного пения. - M. 2002

14.Назаренко И. Искусство пения. - М.-Л. 1948

15.Павлищева О. Методика постановки голоса. - Л. 1964

16.Панофка Г. Искусство пения. - М. 1968

17.Фучито С., Бейер Б. Вокальная методика Энрико Карузо. - СПб. 2004

18.Юшманов В. Вокальная техника и ее парадоксы. - СПб. 2001 